\title{
Elimination of pepper mild mottle virus from infected tobacco (Nicotiana benthamiana L.) plants by callus culture and the sieving technique
}

\author{
Youngsun Kwon • Md. Alamgir Kabir • Hong Wei Wang • \\ Thirupathi Karuppanapandian • Jun-Cheol Moon • \\ Ki Hyun Ryu • Gung Pyo Lee • Wook Kim \\ Received: 14 July 2011 / Accepted: 26 July 2012 /Published online: 20 September 2012 / Editor: Jianxin Chen \\ (C) The Society for In Vitro Biology 2012
}

\section{Introduction}

Pepper mild mottle virus (PMMoV) is a positive-sense, single-stranded RNA virus that belongs to the genus Tobamovirus and often causes significant field and greenhouse crop losses worldwide. Typically, PMMoV is transmitted through the seeds and soil (Kim et al. 2005; Jarret et al. 2008). Various methods are currently available for the

Youngsun Kwon and Md. Alamgir Kabir contributed equally to this study.

T. Karuppanapandian

Institute of Life Science and Natural Resources,

College of Life Sciences and Biotechnology, Korea University,

Seoul 136-713, Republic of Korea

Y. Kwon • M. A. Kabir • W. Kim $(\square)$

Division of Biotechnology,

College of Life Sciences and Biotechnology, Korea University,

Seoul 136-713, Republic of Korea

e-mail: kwook@korea.ac.kr

H. W. Wang

Laboratory for Biosensing, Qingdao Institute of Bioenergy

and Bioprocess Technology, and Key Laboratory of Bioenergy,

Chinese Academy of Sciences,

Qingdao 266-101, People's Republic of China

T. Karuppanapandian · G. P. Lee

Department of Integrative Plant Science, Chung-Ang University, Ansung 456-756, Republic of Korea

J.-C. Moon

Agriculture and Life Sciences Research Institute,

Kangwon National University,

Chuncheon 200-713, Republic of Korea

K. H. Ryu

Plant Virus GenBank, Department of Horticulture,

Biotechnology and Landscape Architecture, Seoul Women's University,

Seoul 139-774, Republic of Korea elimination of viruses from plants, including tissue culture, chemotherapy, and thermotherapy either alone or in combination (Howell et al. 1998; Hosokawa et al. 2004; Sharma et al. 2008). Chemotherapy has been tested for several for its usefulness in virus elimination in combination with meristem culture. However, the technique has met with only limited success and often the role of antiviral compounds in virus suppression or inactivation has been doubtful (Kartha 1986; Cassells 1987). In light of contradictory reports on the effectiveness and phytotoxicity of antiviral compounds (Cassells and Long 1980; Simpkins et al. 1981), chemotherapy has not been generally recognized as an effective method for virus elimination, though recent reports suggest that some antiviral compounds have potential for improving the efficiency of virus elimination when used in combination with meristem and shoot tip culture (Nehra and Kartha 1994). Heat treatment does not eliminate most viruses, but it reduces virus multiplication and translocation in the plant (Roca 1985). Thermotherapy, coupled with shoot tip grafting, has been used to eliminate viruses from kinnow plants (Sharma et al. 2008). High-temperature treatment at $38^{\circ} \mathrm{C}$ for $70 \mathrm{~d}$ was effectively used for the elimination of apple scar skin virus, but this method requires long treatment periods (Howell et al. 1998).

Currently, the most widely used method for virus elimination is meristem tip culture. Because of the way that viruses spread in plants, the efficiency of virus elimination is inversely related to the size of the shoot tip explant (Roca 1985). In addition, the aseptic dissection of the meristem using a binocular dissecting microscope is often a delicate process that requires many hours of practice. Moreover, some additional measures (chemotherapy, thermotherapy, or a mixture of the two) are often used first to enhance the probability of isolating meristems that are virus-free. In vitro growth of the very small explants used in meristem culture is quite slow and callus is often formed, which may be 
undesirable. Callus culture from specific somatic tissues has also been used to eliminate viruses from different plants including grapevines, sugarcane, lily, and kinnow (Goussard and Wiid 1992; Niimi et al. 2001; Gambino et al. 2006; Sharma et al. 2008). Virus-free plants were also obtained from the callus culture of plants infected with tobacco mosaic virus (TMV) (Hansen and Hildebrandt 1966; Murakishi and Carlson 1976).

Eliminating disease depends on several interrelated factors, such as the virus to be eliminated, the size of the explant (for shoot tip culture), and the physical or chemical treatments applied to the infected plants or to the cultures (Roca 1985). The purpose of the present study was to develop a suitable protocol for the eradication of PMMoV from infected tobacco plants following a simple rapid callus disruption and sieving process of obtaining micro-calli to culture under in vitro conditions. This is the first report addressing the elimination of PMMoV from infected tobacco plants by the sieving method.

\section{Materials and Methods}

Plant material, preparation of viral inoculum, and harvesting infected leaves. Tobacco (Nicotiana benthamiana L.) plants were maintained under a 16 -h photoperiod with irradiance of $400 \mu \mathrm{Mol} \mathrm{m} \mathrm{s}^{-1}$ at $25 \pm 1^{\circ} \mathrm{C}$ and a relative humidity of $80 \%$. To prepare the viral inoculum, $1 \mathrm{~g}$ leaves was homogenized with $10 \mathrm{ml}$ of $10 \mathrm{mM}$ sodium phosphate buffer (pH 7.0) and PMMoV-Kr (PMMoV-Kr was obtained from Plant Virus GenBank, Seoul, Republic of Korea; http:// www.virusbank.org). Viral inoculum was applied to the fully expanded lower six to eight leaves of 6-wk-old plants by rub-inoculating with a latex-gloved finger and plants were maintained in a growth chamber as described above. Control plants were mock inoculated with buffer only. The virus-infected leaves were harvested 2 wk after viral inoculation.

Callus culture, monitoring viral infection, and acclimatization of regenerated plantlets. Callus cultures were initiated from virus-infected leaves and grown on medium containing MS salts (Murashige and Skoog 1962), Gamborg's B5 vitamins (Gamborg et al. 1968), $30 \mathrm{~g} / 1$ sucrose, $1 \mathrm{mg} / \mathrm{l}$ benzylaminopurine, $0.1 \mathrm{mg} / 1$ naphthaleneacetic acid, and $8 \mathrm{~g} /$ 1 phytoagar. Calli were grown for $8 \mathrm{wk}$ in a growth chamber under the conditions described above for plant growth until they reached a size $>1 \mathrm{~cm}$. The incidence of virus infection in mother calli was first checked by double-antibody sandwich enzyme-linked immunosorbent assay (DAS-ELISA; described in more detail below) and further confirmed by reverse transcription polymerase chain reaction (RT-PCR; described in more detail below) before they were used for the sieving method. The PMMoV-infected callus (designated as "infected mother callus") was broken into small callus particles and processed using the Cell Dissociation SieveTissue Grinder Kit (Sigma-Aldrich, Inc., St. Louis, MO) under sterile conditions. The micro-calli (about 250, 300, and $425 \mu \mathrm{m}$ in diameter) were then transferred to semisolid media ( $3 \mathrm{~g} / \mathrm{l}$ phytoagar) for callus proliferation. After $6 \mathrm{wk}$ of culture, calli were transferred back to solid media for further growth (Fig. 1). Shoot induction on the medium described previously occurred within 4 wk of culture. Subsequently, the plantlets were regenerated and acclimatized to greenhouse conditions.

Harvesting of leaves, assessment of virus infection by DASELISA, and confirmation by RT-PCR. After $4 \mathrm{wk}$, fully expanded young leaves of greenhouse-grown plants were harvested, frozen in liquid nitrogen, and stored at $-80^{\circ} \mathrm{C}$ until the isolation of total RNA. Leaves from both 1- and 8-mo-old plants were tested and the presence of viruses was confirmed by RT-PCR.

Virus infection was also detected using a DAS-ELISA detection kit (KisanBio, Seoul, Republic of Korea) according to the method of Clark and Adams (1977). Tissue extracts were prepared by homogenizing in phosphatebuffered saline, and the absorbance of the tissue extracts at $405 \mathrm{~nm}$ was measured with an Automated Microplate Reader (model EL 808, Bio-Tek Instruments, Winooski, VT). A reaction was considered positive when absorbance at $405 \mathrm{~nm}$ was 2.5 -fold higher than the negative control. The DAS-ELISA test was performed on positive (PMMoVinfected leaves) and negative (noninfected leaves) controls in four replicates.

Total RNA was isolated from leaf tissues surrounding major veins according to Pérez-Bueno et al. (2006) using the TRIzol Reagent (Invitrogen Corp., Carlsbad, CA). Complementary DNA and PCR amplifications were carried out with the One-Step RT-PCR PreMix Kit (iNtRON Biotechnology, Seongnam, Republic of Korea) using $1 \mu \mathrm{g}$ total RNA as template. For PCR amplifications, primers designed for the amplification of the PMMoV coat protein were used to obtain a fragment with an expected size of $500 \mathrm{bp}$. The reverse transcription reaction consisted of an initial incubation at $45^{\circ} \mathrm{C}$ for $30 \mathrm{~min}$ using the OptiScript ${ }^{\mathrm{TM}}$ RT System (iNtRON Biotechnology, Seongnam, Republic of Korea), inactivation at $94^{\circ} \mathrm{C}$ for $5 \mathrm{~min}, 32$ cycles of amplification (denaturation at $94^{\circ} \mathrm{C}$ for $45 \mathrm{~s}$, annealing at $55^{\circ} \mathrm{C}$ for $45 \mathrm{~s}$, and extension at $72^{\circ} \mathrm{C}$ for $60 \mathrm{~s}$ ), and a final extension at $72^{\circ} \mathrm{C}$ for $5 \mathrm{~min}$. The PCR products were electrophoresed on $1 \%(w / v)$ agarose gels alongside molecular markers to confirm the size of the products, visualized under UV light, and photographed. The primers used for the amplification of PMMoV-CP were 5'-CTTAAGGAGTTGT AGCCCAG-3' and 5'-ATGGCTTACACAGTCTCC-3' as 
PMMoV infected tobacco leaves

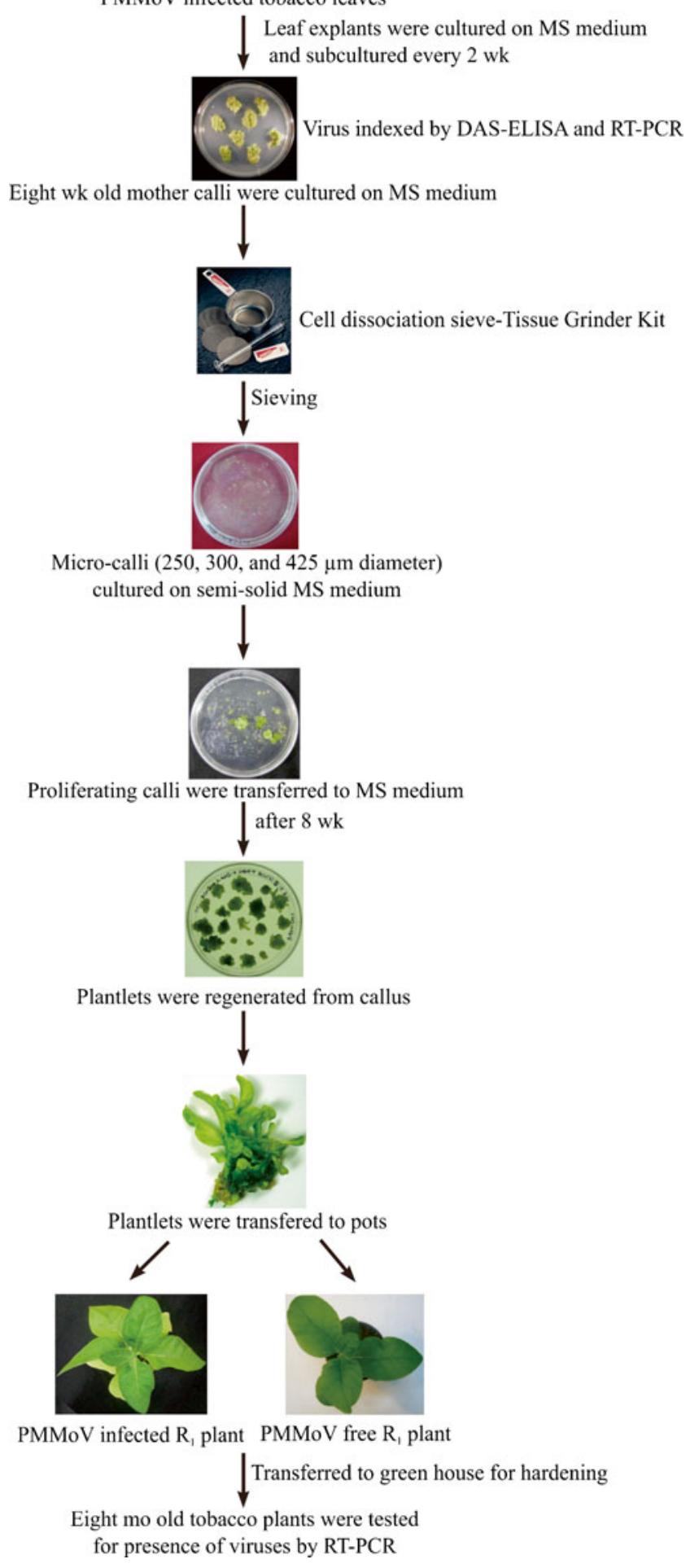

Figure 1. Flowchart showing the protocol used for the elimination of PMMoV from infected tobacco plants.

forward and reverse primers, respectively. The tobacco $18 \mathrm{~S}$ $r R N A$ housekeeping gene (GenBank accession no. AJ236016) was employed as an internal control and amplified using the following primers: forward, 5'-AGGAATTGACGGAAGGG CA-3'; reverse, 5'-GTGCGGCCCAGAACATCTAAG-3'.
Data analysis. Derived data were analyzed with MS Excel. Analysis of variance for treatment (sieve sizes) means was done with the statistical software MSTAT. Treatments were then ranked by Duncan's multiple range tests at $P \geq 0.05$.

\section{Results and Discussion}

In the present study, an efficient protocol was developed for the elimination of PMMoV from infected tobacco plants using micro-calli generated by the sieving method under in vitro conditions. In our study, 8-wk-old PMMoV-infected mother calli were used to produce micro-calli of approximately 250 , 300 , and $425 \mu \mathrm{m}$ diameter using the sieving technique. PMMoV infection of mother calli was first assessed by DAS-ELISA and further confirmed by RT-PCR. The results of the DAS-ELISA showed that all 14 tested mother calli were positive for virus infection, with optical density mean values ranging from 0.246 to 0.415 at $A_{405 \mathrm{~nm}}$, compared with an absorbance of 0.056 for the negative control (Fig. 2A). The virus infection of mother calli was further confirmed by RTPCR, which produced a positive amplification of the expected size $(500 \mathrm{bp})$ in all the infected mother calli compared to the virus-free samples (Fig. $2 B$ shows the results for the fourth replication). The virus infection of mother calli was similar to that previously reported by Duran-Vila et al. (1991) and Navas-Castillo et al. (1995). Disrupted micro-calli were transferred to semisolid MS medium to prevent drying and to enable more efficient uptake of nutrients by the callus. The regeneration of calli of different sizes took place after $6 \mathrm{wk}$ of culture (Fig. 1) despite control of the uniform size during sieving. In the present study, non-embryogenic calli induced from leafy explants showed a positive DAS-ELISA result (data not shown). According to Scagliusi et al. (2002), the distribution of GLRaV-3 in the grapevine callus was heterogeneous, with high concentrations of virus in specific groups of cells. D'Onghia et al. (2001) reported that regenerated citrus plants were free from Citrus psorosis despite the presence of virus infection in $90-100 \%$ of the embryogenic calli from stigma and style cultures. Due to the lack of vascular connection between somatic embryos and parent tissue, the grapevine leafroll-associated virus (GLRaVs), which is phloem-limited, was unable to translocate from infected tissues to somatic embryos through the proliferating callus (without vascular tissue) (Goussard and Wiid 1992). Virus elimination by callus culture has been demonstrated in several plant species, including grapevines, sugarcane, lily, and kinnow (Goussard and Wiid 1992; Niimi et al. 2001; Gambino et al. 2006; Sharma et al. 2008). DAS-ELISA and RT-PCR have been used widely for virus detection because they provide accurate and sensitive means for the detection of molecules that occur at low concentrations in plant tissues (Hosokawa et al. 2004; Verma et al. 2004). 


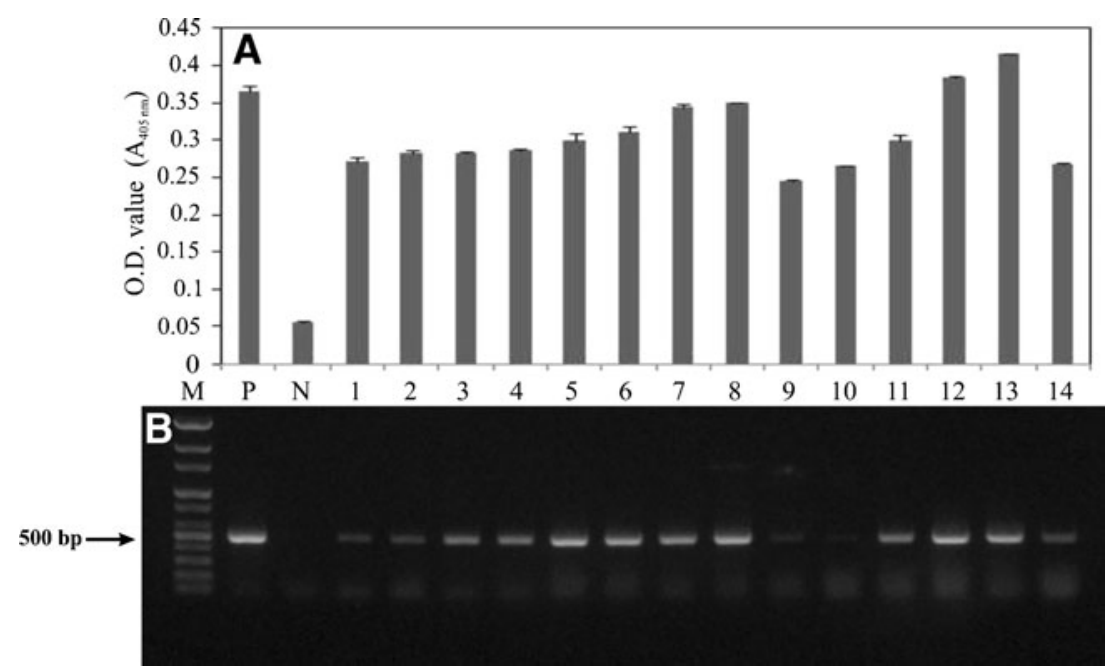

Figure 2. Preparation of infected tobacco mother callus and assessment of infection by DAS-ELISA and RT-PCR. The calli were induced from PMMoV-infected tobacco leaves, and the virus infection was first confirmed by DAS-ELISA $(A)$ and RT-PCR $(B)$ at 8 wk after subculture. For RT-PCR analysis, RNA extracted from individual mother calli

In the present study, PMMoV-specific primers amplified a fragment of the expected size of 500-bp in virus-infected tobacco regenerated plants, while no amplification was obtained with PMMoV-free regenerated plants (Fig. $3 A-C$ shows the result for the fourth replication). Among 27 tested plantlets (for each replication of the experiment) regenerated from micro-calli/sieve size of 250,300 , and $425 \mu \mathrm{m}$ in diameter, 25,9 , and 5 were negative on average, respectively, for PMMoV by RT-PCR, which confirmed that three tested sieve sizes produced significantly different $(P \geq$ 0.00001 ) percentages of PMMoV virus-free tobacco plants and the $250 \mu \mathrm{m}$ sieve size provided the highest percentage was used for PCR amplification. Lane $M 100$ bp ladder molecular weight marker, lane $P$ positive control, lane $N$ negative control, lanes 1-14 amplification of a 500-bp fragment from 14 mother calli induced from PMMoV-infected tobacco leaves.

(91.67 \pm 3.31$)$ of PMMoV virus-free tobacco plants followed by sieve size $300 \mu \mathrm{m}(33.92 \pm 1.08)$ and $425 \mu \mathrm{m}(18.52 \pm$ $1.51)$ under in vitro conditions. This result is consistent with the findings of Toyoda et al. (1985) where TMV virus-free tobacco plantlets were produced only from smaller-sized callus cultures.

Mitosis in the rapidly dividing callus competes with virus multiplication (Roca 1985). The uneven distribution of the virus in mother calli was proposed to be due to the production of virus-infected and virus-free cell clusters during the callus disruption process. Cell injury caused by the disruption process may induce metabolic alterations that lead to

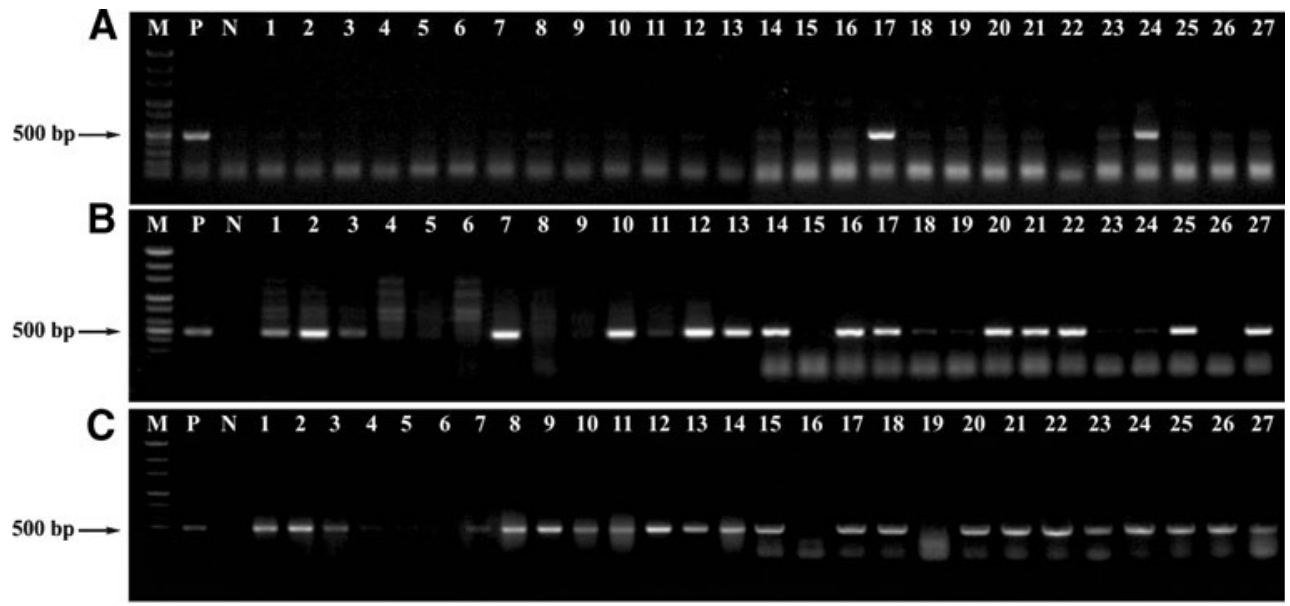

Figure 3. Agarose gel electrophoresis of the products of RT-PCR amplification with PMMoV-specific primers in tobacco plants raised through in vitro callus culture coupled with the sieving method. Lane $M 100$ bp ladder molecular weight marker, lane P positive control, lane $N$ negative control, lanes 1-27 plants were regenerated from PMMoV- infected $250 \mu \mathrm{m}(A), 300 \mu \mathrm{m}(B)$, and $425 \mu \mathrm{m}(C)$ micro-calli, which were confirmed to express the 500 -bp fragment. The presence of a 500 bp band in lanes 17 and $24(A) ; 1-3,7,10,12-14,16-18,20-22,25$, and $27(B) ; 1-3,7-15,17,18$, and $20-27(C)$ indicates PMMoV infection. 
virus degradation. However, as viruses can translocate between cells at a slow pace via plasmodesmata, it is possible that the invasion of viruses through plasmodesmata was limited to the older cells in the callus, while the rapidly proliferating young cells escaped virus invasion. This may also explain the results of previous studies showing the regeneration of virus-free plantlets from callus culture by multiple steps of subculture (Toyoda et al. 1985; Duran-Vila et al. 1991). In the present study, the regenerated plantlets were transferred to the greenhouse and remained virus-free for up to 8 mo (Fig. 1). Visual observation of the plants revealed the absence of symptoms of viral disease. In conclusion, the present study provides a new strategy to effectively eliminate PMMoV from infected tobacco plants through the generation of micro-calli. The disruption and sieving process applied to obtain micro-calli is relatively simple and is not time-consuming. This method may prove to be an alternative way to eradicate viruses and is applicable to other plants, but its feasibility and effectiveness should be evaluated specifically for different plant species and their infecting viruses.

Acknowledgements This research was supported by a grant to W. Kim (code PJ006993) from the BioGreen 21 Program, Rural Development of Administration, Republic of Korea and a Korea University Grant.

\section{References}

Cassells AC (1987) In vitro induction of virus-free potatoes by chemotherapy. In: Bajaj YPS (ed) Biotechnology in agriculture and forestry, vol. 3. Potatoes. Springer, New York, pp 40-50

Cassells AC, Long RD (1980) The regeneration of virus-free plants from cucumber mosaic virus- and potato virus Y-infected tobacco explants cultured in the presence of virazole. Z Naturforsch 35:350-351

Clark MF, Adams AN (1977) Characteristics of the microplate method of enzyme-linked immunosorbent assay for the detection of plant viruses. J Gen Virol 34:475-483

D'Onghia AM, Djelouah K, Frasheri D, Potere O (2001) Detection of Citrus psorosis virus by direct tissue blot immunoassay. J Plant Pathol 83:139-142

Duran-Vila N, Medina V, Pina JA, Ortega C, Molins MI, Navarro L (1991) Growth and morphogenesis of citrus tissue cultures infected with psorosis, vein enation, and cachexia. Phytopathology $81: 824-831$

Gambino G, Bondaz J, Gribaudo I (2006) Detection and elimination of viruses in callus, somatic embryos and regenerated plantlets of grapevine. Eur J Plant Pathol 114:397-404

Gamborg OL, Miller RA, Ojima K (1968) Nutrient requirements of suspension cultures of soybean root cells. Exp Cell Res 50:151158
Goussard PG, Wiid J (1992) The elimination of fanleaf virus from grapevines using in vitro somatic embryogenesis combined with heat therapy. S Afr J Enol Viticult 13:81-83

Hansen AJ, Hildebrandt AC (1966) The distribution of tobacco mosaic virus in plant callus cultures. Virology 28:15-21

Hosokawa M, Otake A, Ohishi K, Ueda E, Hayashi T, Yazawa S (2004) Elimination of chrysanthemum stunt viroid from an infected chrysanthemum cultivar by shoot regeneration from a leaf primordium-free shoot apical meristem dome attached to a root tip. Plant Cell Rep 22:859-863

Howell WE, Burgess J, Mink GI, Skrzeczkowski LJ, Zang YP (1998) Elimination of apple fruit and bark deforming agents by heat therapy. Acta Horticult 472:641-646

Jarret RL, Gillaspie AG, Barkely NA, Pinnow DL (2008) The occurrence and control of pepper mild mottle virus (PMMoV) in the USDA/ARS Capsicum germplasm collection. Seed Technol 30:26-36

Kartha KK (1986) Production and indexing of disease-free plants. In: Withers LA, Alderson PG (eds) Plant tissue culture and its agricultural applications. Butterworths, London, pp 219-238

Kim DH, Cho JD, Kim JK, Kim JS, Cho EK (2005) Ultrastructural characteristics of necrosis and stunt disease in red pepper by the mixed infections of Tobacco mosaic virus-U1 or Pepper mild mottle virus and Pepper mottle virus. Plant Pathol J 21:252-257

Murakishi HH, Carlson PS (1976) Regeneration of virus free plants from dark green islands of tobacco mosaic virus-infected leaves. Phytopathology 66:931-932

Murashige T, Skoog F (1962) A revised medium for rapid growth and bioassays with tobacco tissue cultures. Physiol Plant 15:473-497

Navas-Castillo J, Moreno P, Duran-Vila N (1995) Citrus psorosis, ringspot, cristacortis and concave gum pathogens are maintained in callus culture. Plant Cell Tiss Org Cult 40:133-137

Nehra NS, Kartha KK (1994) Meristem and shoot tip culture: requirements and applications. In: Vasil KI, Thorpe TA (eds) Plant cell and tissue culture. Kluwer Academic, Dordrecht, pp 37-70

Niimi Y, Han D-S, Fujisaki M (2001) Production of virus-free plantlets by anther culture of Lilium x 'Enchantment'. Sci Horticult 90:325-334

Pérez-Bueno ML, Ciscato M, vande Ven M, García-Luque I, Valcke R, Barón M (2006) Imaging viral infection: studies on Nicotiana benthamiana plants infected with the pepper mild mottle tobamovirus. Photosynth Res 90:111-123

Roca WM (1985) In vitro clonal propagation to eliminate crop diseases. In: Proceedings of International Agricultural Research Centers (IARCs) and Biotechnology Inter-Center Seminar held on 23-27 April 1984, International Rice Research Institute, Philippines

Scagliusi SMM, Vega J, Kuniyuki H (2002) Cytopathology of callus cells infected with grapevine leafroll-associated virus 3. Fitopatol Bras 27:384-388

Sharma S, Singh B, Rani G, Zaidi AA, Hallan VK, Nagpal AK, Virk GS (2008) In vitro production of Indian citrus ringspot virus (ICRSV) free kinnow plants employing thermotherapy coupled with shoot tip grafting. Plant Cell Tiss Org Cult 92:85-92

Simpkins I, Walkey DGA, Neely HA (1981) Chemical suppression of virus in cultured plant tissues. Ann Appl Biol 99:161-169

Toyoda H, Oishi Y, Matsuda Y, Chatani K, Hirai T (1985) Resistance mechanism of cultured plant cells to tobacco mosaic virus. J Phytopathol 114:126-133

Verma N, Ram R, Hallan V, Kumar K, Zaidi AA (2004) Production of Cucumber mosaic virus-free chrysanthemums by meristem tip culture. Crop Protect 23:469-473 